\title{
Analisis Keterkaitan antar Komponen dalam Rencana Pelaksanaan Pembelajaran di Sekolah Dasar Kota Sumedang
}

\author{
Poppy Anggraeni \\ Program Studi Pendidikan Guru Sekolab Dasar, Sekolah Tinggi Keguruan dan Ilmu \\ Pendidikan Sebelas April Sumedang \\ e-mail: poppysofia04@gmail.com/poppysofia04@stkip11april.ac.id
}

\begin{abstract}
Lesson planning has a very important role in learning process. Lesson plan or Rencana Pelaksanaan Pembelajaran (RPP) is an activity plan created by the teacher as a guide in the learning process. This RPP consists of various components that must be linked and integrated with each other in accordance with the principles of RPP preparation, including learning objectives, materials, methods/models/approach/strategy, learning/media resources, process/activity, time allocation, and evaluation of learning. The purpose of this study is to analyze and describe the extent to which the related components in the lesson plan used in the learning process at elementary school in City of Sumedang, which includes North Sumedang Subdistrict and South Sumedang Subdistrict. The research method used in this research is descriptive method. The sampling method used is random sampling technique, obtained 23 schools as research subject. The results showed that the level of relevance of each component in the RPP used in the learning process at Sumedang Elementary Schools is in high category, where each component of RPP has been prepared well in accordance with the indicator of the relevance of each component. Similarly, the level of interrelationships between components in the $\mathrm{RPP}$ has a high category, where each component ranging from learning objectives, materials, methods /models/approach/strategy, learning resources/media, process/activities, time allocation, and evaluation of learning has been interrelated one with the other.
\end{abstract}

Keywords: lesson plan, lesson plan component, teacher, descriptive method

\section{PENDAHULUAN}

Pembelajaran merupakan sebuah proses yang sangat kompleks karena di dalamnya melibatkan berbagi komponen pembelajaran yang satu sama lain saling berhubungan dan berinteraksi. Menurut Dick \& Carey (1996) dalam Isman (2011: 136) Instruction is a systematic process in which every component (i.e. teachers, students, materials, and learning environment) is crucial to successfully learning. Menurut Sukirman dan Jumhana (2008: 10) komponen yang terlibat dalam sistem pembelajaran meliputi siswa, guru, materi, metode, media dan sumber belajar, lingkungan fisik maupun non fisik dan sebagainya. Lebih jauh Sanjaya (2008:204) menerangkan bahwa dalam sistem proses pembelajaran komponen-komponennya itu meliputi tujuan, materi pelajaran, metode atau strategi pmbelajaran, media dan evaluasi.

Setiap proses pembelajaran memerlukan perencanaan pembelajaran yang matang. Sukirman dan Jumhana (2008: 33) menyebutkan bahwa hakikat 
perencanaan pembelajaran adalah upaya untuk merancang dan mengembangkan setiap komponen pembelajaran sehingga menjadi satu kesatuan yang utuh, terkait dan saling menentukan untuk mencapai tujuan pembelajaran.

Rencana pelaksanaan pembelajaran adalah rencana pembelajaran yang dikembangkan secara rinci dari suatumateri pokok atau tema tertentu yang mengacu pada silabus.RPP mencakup: (1) data sekolah, mata pelajaran, dankelas/semester; (2) materi pokok; (3) alokasi waktu; (4) tujuanpembelajaran, $\mathrm{KD}$ dan indikator pencapaian kompetensi; (5)materi pembelajaran; metode pembelajaran; (6) media, alat dansumber belajar; (6) langkah-langkah kegiatan pembelajaran;dan (7) penilaian (Permendikbud No 81A, 2013).

Tujuan pembelajaran merupakan rumusan kualifikasi kemampuan (perubahan perilaku) yang harus dicapai oleh siswa setelah melakukan proses pembelajaran. Adapun jenis perubahan perilaku tersebut meliputi pengetahuan (kognitif), sikap (afektif) dan keterampilan (psikomotor). Metode pembelajaran merupakan salah satu komponen yang berpengaruh terhadap keberhasilan pencapaian tujuan pembelajaran. Metode ini diaplikasikan dalam kegiatan pembelajaran untuk menciptakan proses pembelajaran yang berkualitas yang memungkinkan siswa melakukan berbagai aktifitas fisik maupun non fisik (Sanjaya, 2008: 206).

Materi pelajaran adalah bahan atau isi yang harus dipelajari siswa. Materi pembelajaran yang akan diberikan kepada siswa terlebih dahulu harus direncanakan, dikembangkan dan dikelola secara matang baik menyangkut ruang lingkup (scoop), urutan (squence), keberlanjutan (continuity) dan keterpaduan (integrated) (Sukirman dan Jumhana, 2008:63).Sedangkan evaluasi pembelajaran befungsi ungsi untuk melihat keberhasilan siswa dalam proses pembelajaran dan sebagai umpan balik bagi guru atas kinerjanya dalam pengelolaan pembelajaran.

Penelitian Isman et all., (2003) menyimpulkan bahwa pembelajaran di kelas yang tidak menggunakan RPP menunjukkan bahwa anak-anak berbicara satu dengan yang lainnya dan tidak konsentrasi terhadap guru, sedangkan kelas yang menggunakan RPP menunjukkan siswa yang sangat focus dan turut berpartisipasi terhadap guru.Sedangkan penelitian Febriyanti (2014: 7) menyimpulkan adanya relevansi antarkomponen RPP dalam mata pelajaran Bahasa Indonesia Kelas VII SMP Negeri 1 Genteng menunjukkan kesesuaian antarkomponen dalam RPP yang meliputi KI, KD, indikator, tujuan, materi pembelajaran, metode, scenariopembelajaran, dan penilaian.

Lebih jauh hasil penelitian Lubis, Djulia dan Hasruddin (2017) terhadap perencanaan pelaksanaan pembelajaran yang dibuat oleh guru biologi di SMA Negeri Se Kabupaten Mandailingnatal pada materi sistem reproduksi tahun ajaran 2015/2016 tergolong kriteria terencana dengan cukup baik dengan persentase 77\%, yang meliputi identitas RPP, SK dan KD, perumusan indikator pembelajaran, perumusan tujuan pembelajaran, pemilihan materi, pengorganisasian materi, sumber/media pembelajaran, skenario pembelajaran, kerincian scenario pembelajaran dan kelengkapan instrument pembelajaran. 
Hasil penelitian sebelumnya lebih memfokuskan pada peran penggunaan RPP, dan mefokuskan pada relevansi antar komponen dalam RPP di SMP dan kriteria perencaan pembelajaran di SMA, maka pada penelitian ini akan difokuskan pada penelitian mengenai keterkaitan antar komponen dalam perencanaan pembelajaran terutama dalam Rencana Pelaksanaan Pembelajaran yang dibuat oleh guru di Sekolah Dasar.

Penelitian ini dilakukan mengingat betapa pentingnya RPP dalam proses pembelajaran, oleh karenaitu sudah menjadi suatu kewajiban bagi setiap guru untuk mampu membuat dan merancang sebuah perencanaan pembelajaran dalam hal ini RPP dengan berdasarkan pada prinsip keterkaitan dan keterpaduan. Implikasinya adalah bahwa RPP harus dibuat dengan berdasarkan pada keterkaitan mulai daripengembangan tujuan, isi, metode dan media serta sumber belajar, dan evaluasi pembelajaran sehingga menjadi suatu sistem yang utuh yang dapat dijadikan pedoman dalam kegiatan pembelajaran. Adapun tujuan penelitian ini adalah untuk menganalisis serta mendeskripsikan mengenai keterkaitan antar komponen dalam RPP yang dibuat oleh guru Sekolah Dasar di Kota Sumedang.

\section{METODOLOGI}

Metode yang digunakan pada penelitian ini adalah metode deskriptif. Pemilihan sampel dari populasi yang ada menggunakan teknik random sampling, dengan memilih secara acak sampel yang akan digunakan,sehingga dari 81 Sekolah Dasar Negeri dan Swastayang terdapat di Kota Sumedang diperoleh sebanyak 23 sekolah sebagai bahan penelitian. Pemilihan sampel jumlah sekolah ini dilakukan berdasarkan standar 15-20\% dari jumlah populasi (Ridwan, 2009: 119). Teknik pengumpulan data yang digunakan yaitu teknik dokumentasi dengan mengambil dokumen RPP yang digunakan oleh guru untuk satu kali kegiatan pembelajaran. Dokumen RPP ini kemudian dianalisis keterkaitan antar komponennya kemudian dilakukan pengkategorian berdasarkan standar berikut ini.

Tabel 1. Kriteria Kesesuaian antar Komponen dalam RPP

\begin{tabular}{cc}
\hline Persentase (\%) & Kriteria \\
\hline $81-100$ & Sangat Tinggi \\
$61-80$ & Tinggi \\
$41-60$ & Cukup \\
$21-40$ & Rendah \\
$0-20$ & Sangat Rendah \\
\hline & Sumber: (Arikunto, 2006: 239)
\end{tabular}

\section{TEMUAN DAN DISKUSI}

\section{Deskripsi Keterkaitan dalam Setiap Komponen RPP}

Analisis terhadap keterkaitan dalam setiap komponen RPP dilakukan dengan cara melihat komponen RPP yang meliputi tujuan pembelajaran, materi, metode/model/pendekatan/strategi, sumber belajar/media, proses/kegiatan, 
alokasi waktu, dan evaluasi pembelajaran, kemudian menganalisisnya sesuai dengan indikator yang terdapat pada setiap komponen RPP tersebut. Temuan terhadap keterkaitan dalam setiap komponen RPP dapat dilihat pada gambar 1 berikut ini.

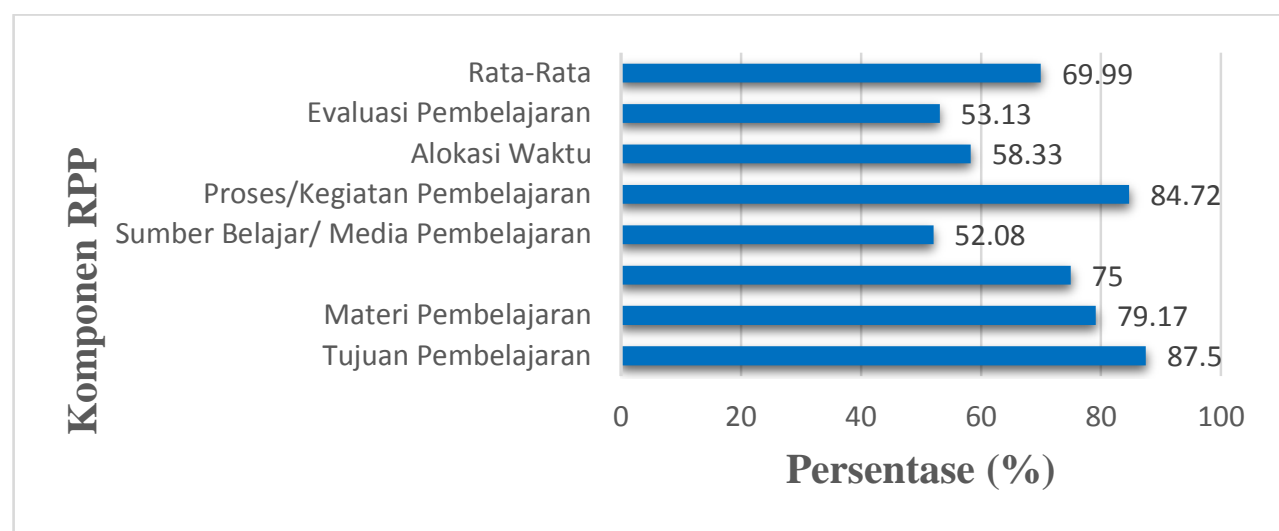

Gambar 1. Grafik Keterkaitan Setiap Komponen dalam RPP

Berdasarkan uraian di atas dapat diketahui bahwa keterkaitan RPP yang digunakan pada proses pembelajaran di Sekolah Dasar Kota Sumedang untuk setiap komponennya sangat bervariasi, mulai dari kategori cukup, tinggi hingga sangat tinggi. Berdasarkan pada grafik dapat diketahui bahwa pada komponen tujuan pembelajaran memiliki kategori keterkaitan sangat tinggi. Artinya pada komponen tujuan pembelajaran, untuk perumusan tujuan pembelajaran telah memenuhi kompetensi dasar yang digunakan, selain itu juga rumusan tujuan pembelajaran telat sesuai dengan indikator yang diharapkan.

Pada komponen materi pembelajaran memiliki kategori keterkaitan tinggi. Artinya pada komponen materi pembelajaran materi pokok yang dipilih sudah berdasarkan pada tujuan pembelajaran atau kompetensi yang ingin dicapai. Selain itu tingkat keluasan dan kedalam materi yang akan dicapai juga sudah sesuai dengan waktu yang disediakan. Pada komponen metode/model/pendekatan/strategi pembelajaran memiliki kategori keterkaitan tinggi. Artinya pada pemilihan metode/model/strategi ini sudah relevan atau memiliki keterkaitan dengan tujuan pembelajaran yang ingin dicapai, memperhatikan perkembangan kognitif, apektif dan psokomotor peserta didik, serta media dan sumber belajar yang digunakan.

Pada komponen sumber belajar/media pembelajaran memiliki kategori keterkaitan cukup. Artinya sumber/media pembelajaran yang akan digunakan sudah cukup dirancang dengan berdasarkan pada tujuan pembelajaran yang ingin dicapai, materi/tema yang akan diajarkan, kreatif, inovatif dan cukup bervariatif. Pada komponen proses/kegiatan pembelajaran memiliki kategori keterkaitan sangat tinggi. Artinya pada kegiatan pembelajaran telah tersusun secara sistematis telah dijelaskan secara rinci mulai dari kegiatan awal, inti, dan penutup dan telah memenuhi kesesuaian dengan tujuan pembelajaran.

Pada komponen alokasi waktu memiliki kategori keterkaitan cukup. Artinya pengalokasian waktu untuk kegiatan awal inti dan penutup sudah cukup proporsional. Pada komponen evaluasi pembelajaran memiliki kategori keterkaitan cukup. Artinya alat evaluasi yang disusun yang meliputi penilaian proses dan hasil 
belajar sudah cukup memiliki keterkaitan dengan indikator dan tujuan pembelajaran yang ingin dicapai. Selain itu alat penilaian yang tercantum dalam RPP juga sudah mencantumkan soal dan kunci jawaban.

Secara umum dapat diketahui bahwa tingkat keterkaitan dalam setiap komponen RPP yang digunakan dalam proses pembelajaran di Sekolah Dasar Kota Sumedang ini berada pada kategori tinggi. Dengan demikian dapat dikatakan bahwa guru telah mampu dalam mengembangkan setiap komponen yang ada dalam RPP berdasarkan pada keterkaitannya dengan indicator setiap komponen RPP.

\section{Deskripsi Keterkaitan Antar Komponen RPP}

Analisis terhadap keterkaitan antar komponen RPP dilakukan dengan cara melihatsemua komponen RPP yang meliputi tujuan pembelajaran, materi, metode/model/pendekatan/strategi, sumber belajar/media, proses/kegiatan, alokasi waktu, dan evaluasi pembelajaran, kemudian menganalisisnya secara keseluruhan sehingga diketahui persentase dan kategori keterkaitannya. Temuan terhadap keterkaitan antar komponen dalam RPP untuk 23 Sekolah Dasar di Kota Sumedang inidapat dilihat pada gambar 2 berikut ini.

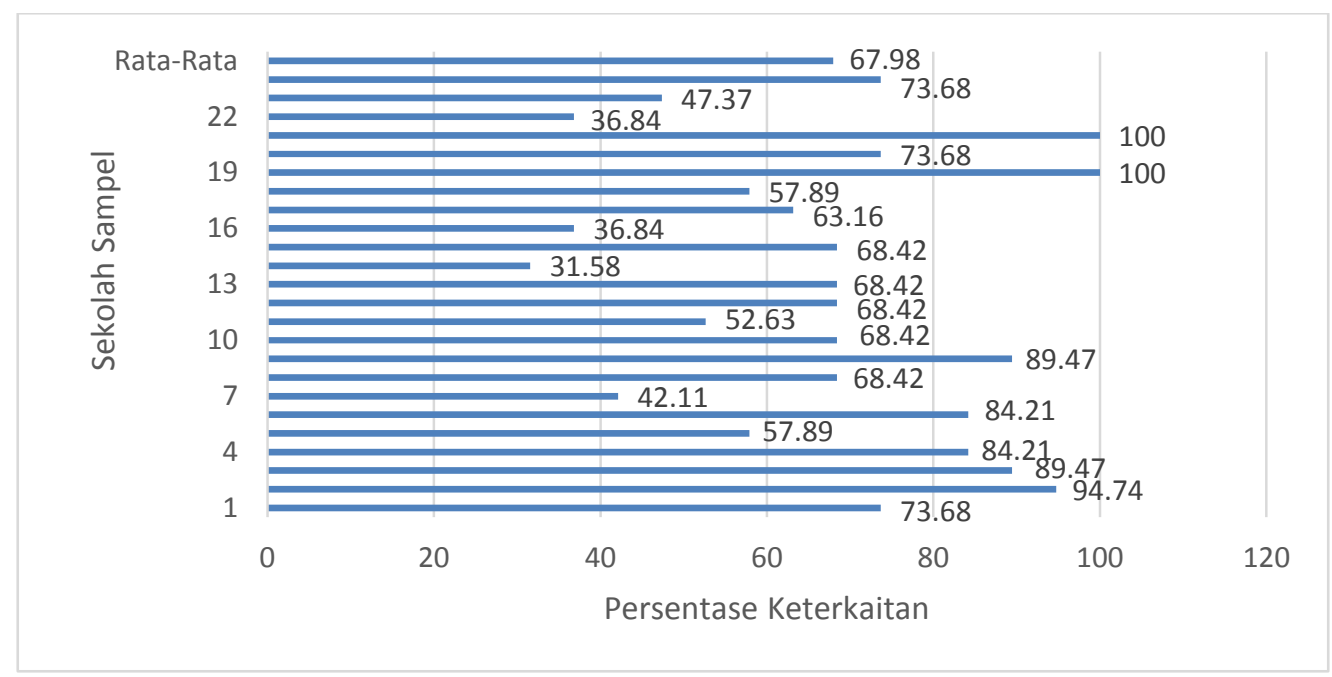

\section{Gambar 2. Grafik Keterkaitan Antar Komponen RPP di Sekolah Dasar Kota Sumedang}

Berdasarkan gambar di atas dapat diketahui bahwa keterkaitan antar komponen RPP pada setiap sekolah berbeda-beda, dalam hal ini tingkat keterkaitannya bervariasi mulai dari kategori sangat tinggi, tinggi, cukup sampai rendah. Grafik mengenai penyebaran kategori keterkaitan antar komopnen RPP di Sekolah Dasar Kota Sumedang dapat dilihat pada gambar 3 berikut ini. 


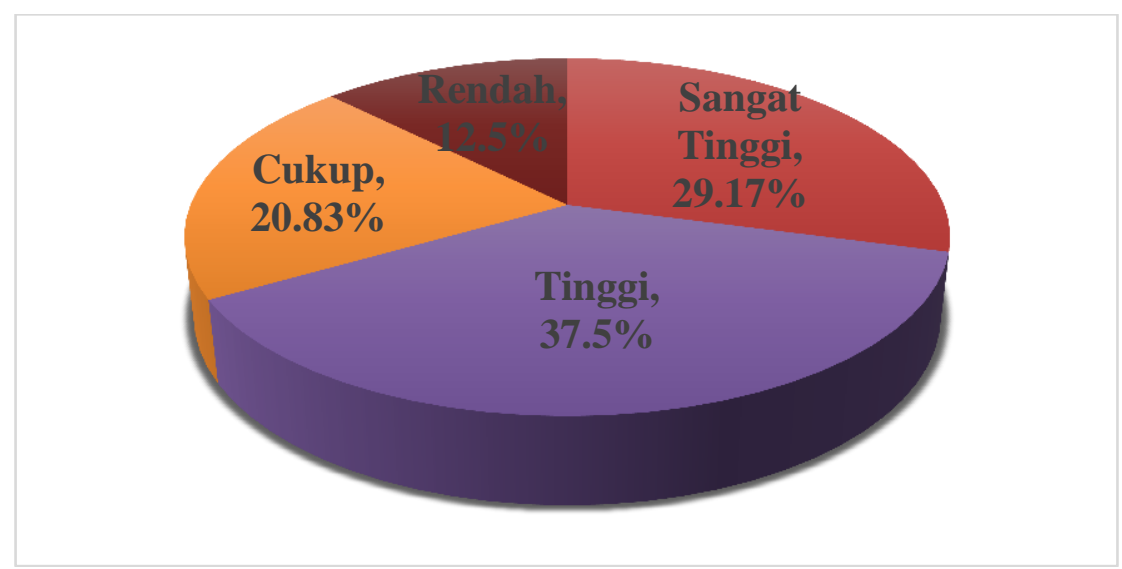

Gambar 3. Grafik Penyebaran Kategori Keterkaitan Antar RPP

Ada 3 sekolah yang memiliki tingkat keterkaitan antar komponen RPP rendah, temuan di lapangan menunjukkan bahwa terdapat kurangnya keterkaitan antara komponen metode/model/pendekatan/strategi, sumber belajar/media, dan evaluasi pembelajaran. Seperti misalnya untuk komponen metode/model/pendekatan/strategi rumusannya tidak disusun berdasarkan keterkaitannya dengan perkembangan kognitif, apektif dan psikomotor siswa serta kurang sesuai dengan media dan sumber belajar yang digunakan. Demikian halnya dengan komponen sumber belajar/media pembelajaran yang rumusannya kurang kreatif, inovatif dan tidak bervariasi, kemudian untuk komponen penilaian baik penilaian proses maupun hasil belajaranya tidak disusun berdasarkan tujuan dan indikator pembelajaran, bahkan penilain dan kunci jawaban evaluasinya tidak dicantumkan sama sekali.

Namun demikian secara umum dapat diketahui bahwa tingkat keterkaitan RPP yang dibuat oleh guru Sekolah Dasar di Kota Sumedang berada pada kategori tinggi, dimana seluruh komponennya mulai dari tujuan pembelajaran, materi, metode/model/pendekatan/strategi, sumber belajar/media, proses/kegiatan, alokasi waktu, dan evaluasi pembelajaran sudah sangat terkait satu sama lain.

Tujuan dari penelitian ini adalah untuk mendeskripsikan mengenai sejauh mana keterkaitan komponen - komponen dalam RPP yang digunakan pada proses pembelajaran di Sekolah Dasar di Kota Sumedang. Hasil penelitian ini diharapkan dapat memberikan kontribusi bagi pembelajaran yaitu bagi guru, untuk memperoleh informasi mengenai keterkaitan antar komponen RPP yang dibuat oleh guru, sehingga bermanfaat dan menjadi bahan evaluasi bagi peningkatan kompetensi guru terutama dalam mengembangkan dan menyusun RPP. Sedangkan bagi Sekolah, yaitu untuk memperoleh informasi mengenai keterkaitan antar komponen dalam RPP yang dibuat oleh guru di Sekolah Dasar, sehingga menjadi bahan untuk evaluasi dan refleksi bagi program pengembangkan dan penyusunan RPP.

Berdasarkan pada hasil analisis menunjukkan bahwa baik keterkaitan dalam setiap komponen RPP maupun antar komponen dalam RPP yang digunakan dalam proses pembelajaran memiliki keterkaitan yang tinggi. Dengan demikian dapat dikatakan bahwa RPP yang digunakan sudah dirumuskan atau disusun dengan 
berdasarkan pada kesaling terkaitan dan kesaling terpaduan antar komponen yang satu dengan komponen yang lain, mulai dari rumusan komponen tujuan pembelajaran, materi, metode/model/pendekatan/strategi, sumber belajar/media, proses/kegiatan, alokasi waktu, dan evaluasi pembelajaran.Hal ini sesuai dengan prinsip dalam mengembangkan atau menyusun RPP yang salah satunya adalah keterkaitan dan keterpaduan (Permendiknas No 81A, 2013).

Adapun implikasi dari penelitian ini berdasarkan pada temuan yang telah dipaparkan di atas adalah bahwa baik keterkaitan dalam setiap komponen RPP maupun antar komponen dalam RPP yang digunakan dalam proses pembelajaran memiliki keterkaitan yang tinggi. Hal ini akan memberikan pandangan yang positif bahwa rumusan RPP tersebut telah memenuhi salah satu prinsip penyusunan RPP, dengan demikian dapat dikatakan bahwa guru sudah mampu untuk merancang dan membuat suatu perencanaan pembelajaran yang baik dalam hal ini RPP untuk dijadikan panduan atau pedoman dalam proses pembelajaran.

Mengingat pentingnya perencanaan pembelajaran dalam suatu proses pembelajaran, Sukirman dan Jumhana (2008: 19) menyatakan bahwa perencanaan pembelajaran (instructional design) merupakan perkiraan atau proyeksi dari tindakan atau aktivitas yang akan dilakukan pada saat pembelajaran, selain itu perencanaan pembelajaran juga dapat berfungsi sebagai pedoman atau panduan kegiatan, menggambarkan hasil yang akan dicapai, sebagai alat kontrol dan sebagai alat evaluasi.

Penulis menyadari adanya keterbatasan dalam penelitian ini, sehingga diharapkan penelitian ini dapat menjadi penelitian pendahuluan bagi penelitian lebih lanjut mengenai analisis RPP. Penelitian lanjutan yang dapat dilakukan adalah terutama mengenaikesesuaian antara indikator atau tujuan pembelajaran dengan butir item alat evaluasi pembelajaran, yang dalam temuan penelitian ini menunjukkan adanya beberapa RPP yang bahkan tidak mencantumkan soal evaluasi pembelajaran.

\section{REFERENSI}

Febriyanti. A. L. (2014). Analisis Rencana Pelaksanaan Pembelajaran Teks Hasil Observasi Dalam Mata Pelajaran Bahasa Indonesia Kelas VII SMP Negeri 1 Genteng Tahun Ajaran 2014/2015. Skripsi Universitas Jember. Tidak diterbitkan.

Isman, A. (2011). Instructional Design in Education : New Model. The Turkish Online Jurnal of Educational Technology. January-Vol 10 Issue 1.136-142. http://tojet.net/articles/v10i1/10114

Isman, et all (2003). Effects of Instructional Design on Learning. International Journal of $\begin{array}{lllll}\text { Computational Intelligence. } & \text { Vol } & 1 & \text { N1. }\end{array}$ https://eric.ed.gov/?id=ED496571

Lubis, Djulia dan Hasruddin. (2017). Analisis Komponen RPP Guru Biologi di SMA Negeri Se-Kabupaten Mandailingnatal. Jurnal Pendidikan Biologi, Vol. 6, No. 3, 367-370. 
Permendikbud No 81A.(2013). Tentang Implementasi Kurikulum. Jakarta : Kemendikbud.

Sanjaya, W. (2008). Kurikulum Dan Pembelajaran Teori Praktik Pengembangan Kurikulum Tingkat Satuan Pendidikan (KTSP). Jakarta: Kencana Predana Media Grup.

Ridwan. (2009). Metode dan Teknik Menyusun Proposal Penelitian. Bandung: Alfabeta.

Sukirman, D. dan Jumhana, N. (2008). Perencanaan Pembelajaran. Bandung: UPI Press. 